the ordinary description, or only a small quantity of it, a sedimentary matter has been found having a very strong general resemblance to Sarcina, though its appearance has been such as to make it almost certain that it is a kind of modified crystalline matter (perhaps somewhat analogous to Mr. Rainey's calculi), rather than a living substance. This variability, moreover, is not confined to the Sarcina which I have met with in my experiments; it is met with, also, in that from the stomach. Robin's figures (loc. cit., pl. xii, fig. I) show a considerable variation in the ultimate pattern of different specimens of Sarcina.

These, and other facts and opinions with reference to Sarcina and somewhat similar products, have for some time been embodied in my work on the The Beginnings of Life, which is shortly to appear. And now it seems to me that such views are strengthened by Dr. Ferrier's recently recorded observations.

Sarcina has been found by him in cases where there has been an " entire absence of putrefactive changes, and no trace of any of the common organisms." He says : "The blood in which sarcinæ had developed to an enormous extent, always retained its alkalinity. There was no sign of putrefaction or fermentation, and no gaseous evolution." Now, I am inclined to believe that it is absolutely impossible for any real living germs to develope to an "enormous extent" in any fluid without an obvious amount of "gaseous evolution" occurring. If, as Dr. Ferrier tells us, this is not the case with Sarcina, we are driven to conclude either that Sarcina is wholly different in this fundamental respect from all other fungus-germs, or else that it is not a living organism at all.

My object in making the present remarks has been merely to direct the attention of Dr. Ferrier and other workers to some of the difficulties which have appeared to me to beset this question, in order that, if possible, they may throw some additional light upon the subject.

In case others should try to procure Sarcina in ammonic tartrate and sodic phosphate solutions, I may as well state that, although I have met with it on ten or twelve different occasions in such fluids, it is by no means to be produced at will. On many occasions I have failed to obtain it, although the solutions and the conditions were, so far as I could make them, similar to those which had yielded Sarcinæe on previous occasions. My occupation with other more important parts of the investigation, in the course of which these curious products were found, has hitherto prevented my making any more thorough observations concerning their nature, and their mode of origin in such solutions.

\section{KOUMISS IN THE TREATMENT OF PHTHISIS.}

\section{By VICTOR JAGIELSKI, M.D.}

THE study of the history of any country naturally comprises the consisideration of the habits, diet, and domestic arrangements of its people. Thus old historical records mention the use of koumiss in Tartary, and bland in Shetland. In Tartary, koumiss has been specially favoured as a beverage from time immemorial, through the influence of religious observances; for, not being a distilled liquor, it escapes the Moham medan proscription, "Qui Muhammedi doctrinam sequuntur, lege Corano præscriptâ vinum adustum sumere vitantur," says one of the authors on that country. This ban gives that country prohibition against mania potatoria and delirium tremens, which, as well as phthisis, are amongst the unknown indigenous diseases in Tartary.

It is the general cause of the latter disease, and the immunity from it, which characterise the region of the Kirghese steppes, that I will now discuss. Popular belief ascribes this exemption to climatic features in some parts, and to peculiarities of soil, etc., in others ; but throughout all Russia the opinion prevails, that the common use of koumiss as both drink and food is the paramount cause.

According to Dr. E. Charlton of Newcastle, Iceland and the Faroe Islands are blessed in this respect for similar reasons as Tartary; the whey-like liquor which he mentions as the national beverage there being only a modification of koumiss. The views of Dr. Charlton are confirmed by the several writers upon Iceland and the islands of Shetlands whose works I have consulted in this connexion.

Dr. Williams's suggestion, that the use of "Muggy" is the reason of this exemption in Iceland, does not hold good for Tartary, as my own knowledge enables me to state that cod-liver oil is not employed there under any name.

This common cause, operating with such happy effect in countries so widely distant, is a pleasing study for all impartial observers. My observations and experience lead me to the conclusion that it is the diet of fermenting milk, and not topographical influence, which produces this exemption among two peoples so different as the Kirghese Tartars and the northern islanders. Though in one country the koumiss is made from mare's milk, and in the other from cow's milk, the product is practically the same, as it would be also if made from any other kind of animal milk, by proper adjustments. As I can see no other point of agreement between these two countries as to their exemption from phthisis, the conviction forces itself upon me, that the coincidence can only be due to the use of koumiss, bland, or syre.

It is a historical fact, that those people who may habitually consume these dietetic substances are free from consumption, provided there be no hygienic influences in conflict with this diet. I use the titles koumiss, bland, and syre, synonymously; for they belong to the same ancient Scandinavian beverage, in one or other of its modified forms, called in Tartary koumiss, in Shetland bland, and in Iceland syre, and which has been introduced by me in British practice under the names of "full", "medium", and "whey" koumiss. As koumiss proper, however, contains all the caseine of the milk, it is much more nutritious than the bland or syre, or whey-koumiss.

The tendency of koumiss to produce a layer of fat on the subcutaneous cell-tissues in a comparatively short time, its great value in improving the digestive powers, and in promoting the due assimilation of food, prevent the decay and waste of weakly constitutions, to which all phthisical persons are liable. This is a fact which no one can deny who has ever had any experience in the use of koumiss; for it is ever prompt to justify its claim to the foremost rank as a means of preventing disease, no less than as a curative when disease has commenced.

The deductions from Dr. Charlton's own experience teach us that, in proportion as this beverage has been left off in Shetland, and tea and coffee have been substituted, so has phthisis increased.

Tartary, where the native cases of incipient phthisis are very rare, offers, according to all travellers and professional gentlemen who have resided there for some time, some particulars which are of interest, and worthy of explanation in this place. That country belongs, according to Alexander von Humboldt, to the so-called "continental climate", where the summer is exceedingly dry, the heat very great, with scarcely any rain; whereas in winter continuous frosts are prevalent. But that it cannot be this climate which assures an almost complete exemption from phthisis, becomes obvious from the fact that consumptives who may reside there, without using the koumiss treatment, would suffer collapse as soon as and sooner than anywhere else. Besides, we know to-day how it victimises the poor invalids to send them to a climate of high temperature. The tubercular deposits tend here more easily to softening. The constitution becomes weaker, flabbier. Local and general liquefaction and colliquation are thus caused prematurely. To avoid these consequences, a retreat to a higher level and a cooler temperature is now preferred for consumptive patients. French physicians select places which have the proper conditions both for summer and winter residence.

Generally, it is believed that malaria gives immunity from tubercular lung-disease. Negroes, who stand best of all the hottest climate, suffer chiefly with consumption; but they enjoy an almost complete exemp. tion from malarial diseases. The natural inference is, that a temperate region is the more suitable for the residence of consumptive patients, and that an absolute curative influence cannot be ascribed to any climatic condition.

Protection from certain injurious winds, and other advantages of a favourable position, are decidedly points of great importance in the choice of a place best suited for our patients. High elevations afford only a temporary relief, unless patients make their residence permanent there. But, reason as we may, the fact presses upon our conviction, that the real focus for attention is the process of nutrition; and it is equally obvious that we must also consider, in this connexion, general dietetic and hygienic rules. Koumiss, then, by reason of its chemical and therapeutic properties, is a most advantageous means of treating phthisis, whether preceded or accompanied by bronchitis or pneumonia in a weakly constitution; but it is observed that residence during a hot season in Tartary is merely an agreeable auxiliary to the koumiss treatment, by enabling patients to drink koumiss much more freely. A liberal and uninterrupted perspiration carries off rapidly all the water of the koumiss which is not excreted otherwise. But mare'smilk koumiss would prove much more inefficient in a cooler climate than in a hot one. Therefore I always prescribe the cow's full koumiss, which suits best this climate. The benefit from mare's-milk koumiss is considerably retarded by cold and wet. This is natural, when we remember that, if very large quantities of koumiss must be drank in order to be effective, this can be done with impunity only by the powerful aid of a free action of the skin and kidneys. In summer copious perspiration is the bodily safety-valve of the animal heat and health. In winter, we know that diuresis takes its place; but at the same time we must not forget that, through the elimination of a large 
quantity of water continually ingested, a certain amount of bodily heat will be alienated, which the organism cannot lose without manifesting a resentment, either by the nervous system, as an unpleasant feeling of cold, or by some secondary derangement of more or less gravity in the digestive functions. However beneficial this effect of lowering the temperature of the body may be in the treatment of fever-complications, it will not generally add to the comfort of emaciated patients. It is, therefore, necessary to raise the plastic ingredients of the koumiss, and equally to diminish the watery parts-without, however, lessening the products of fermentation, so important through their particular sanative properties. This purpose is readily obtained by the process of artificial condensation by evaporation in the slow way, or by adding to the bulk of a good genuine milk the necessary amount of solids in a quick way.

Wanklyn's analytical results of the British koumiss show that it manufacturer has adopted these indications as guides in the preparation of the several varieties of koumiss. Thus are explained the distinctions as to consistence of the full koumiss, medium koumiss, and whey-koumiss, which again are subclassified respectively as Nos. I, 2, and 3 koumiss, according to their age and therapeutical effects. I have in this way created a series of different koumiss-consistencies from one and the same cow's milk, and thereby realised Professor Lebert's prescriptions (on Milch and Molken-Kiven). He recommends the various sorts of natural milk in their order, determined by their chemical composition, for different stages of this disease. In such a table, sheep's milk would represent the most condensed or richest form. But it is superfluous to recall the great difference between a natural milk and the corresponding koumiss, as we know that even the heaviest milk, when converted into koumiss, becomes easily digestible.

Medium koumiss stands the nearest to the composition of mare'smilk koumiss ; but I preferred even herein to make a slight alteration in favour of our patients. This consists in fixing the amount of caseine and sugar a little higher than in mare's milk, and the mineral salts somewhat higher than in full koumiss. This medium koumiss requires the greatest care and attention; but it is the most palatable and pleasant form of koumiss.

Both sorts of cow's koumiss, full and medium, are, in their general properties, more or less alike; but the aperient property of No. I is far more pronounced in the "full" koumiss. We obtain here from both kinds, when properly used, the same, and sometimes even speedier, effects, from proportionately small quantities, than in Tartary from large amounts. We may even be compelled to restrict the diet of patients to koumiss alone; and, contrary to our expectation, more particularly in these cases we obtain the most striking results. Patients themselves even are at first very incredulous about the ability of maintaining their body in good working order upon an exclusive diet of koumiss; but a different opinion comes over them in a few days, as their taste for it improves, and their weight increases. It needs often all the persuasive power of a physician to keep his patient to an exclusive diet of koumiss. There is mostly a longing for some supplementary solid food, as the fact of koumiss being a nutriment and medicine combined is at first difficult to be believed.

Respite from labour and anxieties of business, we know, will always add to the efficiency of any treatment, and more particularly to that of a dietetic one. Purity of air and suitable temperature are both requirements for which great sacrifices of personal convenience are justifiable ; but the climate of any country will be suitable for koumisstreatment by adjusting the kind and dose of koumiss to the attendant circumstances.

As it may be interesting to the reader to hear the opinion of some trustworthy authority on the above points, I quote the following description from Baron Dr. De Maydell's book on Orenburg, where he resided for upwards of six years-a book difficult of access in this country. "Magis æstate caloribus acerrimisque tempore hiberno frigoribus, quæ tantopere invicem se excipiunt, præcipue accidet, ut inflammationes varii generis, præsertim organorum respirationi inserventium, tam crebro Orenburgi reperiri soleant." Apoplexy and dysentery are frequent, in consequenee of the great barometrical variations ; and "febris intermittens," says he, "omnino endemica exstitit, atque ita Orenburgi domicilium suum fixisse videtur, ut non nisi paucos ex incolis reperias, qui eo morbo nunquam laboraverint." Any disease, indeed, may become complicated with or end in intermittent or gastric fever. The question here suggests itself, whether the frequency of intermittents tends to promote an immunity from phthisis. I believe in the negative, because otherwise all malarial places would be exempt from phthisis.

If there be occasional cases of inflammations of the lungs as a consequence of the vicissitudes of the climate, then there must be also cases where pneumonia passes into phthisis. My researches on this point proved the affirmative. There is often observed a want of reso. lution of the disease in native patients suffering from pneumonia, which presents, in its chronic state, the character of phthisis, locally and generally. But the native instinct and popular belief in the restorative power of koumiss are so great, that invalids prescribe it for themselves, and are rewarded for their faith by speedy and marvellous effects in the improvement of their health. The same must be said of chronic bronchitis.

Baron de Maydell says, in reference to the above: "Phthisis pulmonalis non ita raro occurrit (Orenburgi), effecta illa quidem iisdem quibus pulmonum inflammationes causis. Ea vel ut exitus inflammationis pulmonum apparet, vel, nullâ inflammatione pregressâ, continuâ istarum rerum nocentium vi progenitâ intrare solet. Remedium Orenburgi semper adversus hanc affectionem adhibitum, eamque ob causam haud immerito tantis laudibus cerebratum, in potione quâdam consisitt ex lacte equino paratâ, nomineque kumiss appellitatâ... . Phthisis, is quidem $a b$ iis discesserimus casibus, ubi syphiliticum malum jam inveteratum haud dubiè a Russis ad Kirgisos translatum aut affectiones cariosæ subsequebantur, ego ne semel quidem observavi, unde omnino raro invenivi, nequaquam infiteor, tamen, non nisi rarum fore, inde concludas, quod Kirgisi per totam æstatem potione illâ kumis dictâ utuntur, quam quidem omnia quæ in promptu sunt ad phthises oppugnandas medicamenta longe superare, non est, quod negemus. Ea potio ex lacte equino paratur, quod sibi illud peculiare vindicat, ut nunquam coagulet et brevi tempore in fermentationem spirituosam abeat. Sapore potio illa perquam jucundo excellit, quo accidit, quod admodum est nutribilis et immensa ejus copia sine damno hauriri potest. Quæ potionem sumptam subsequuntur phenomena, inclinatio ad dormiendum, adauctus toto corpore calor, sudor atque urinæ aquaticæe secretio solito largior afferenda erunt, quo pressionis cujusdam sensus in vesicâ urinariâ perceptus additur, qui tamen initio tantum animadversus, brevi totus evanescit. Potionis usum si per aliquod tempus continuaveris, coëundi desiderium accrescit, pletora exstitit, quæ ne noxiam vim inferat, multum ut corpus moveas et agites, efflagitat, simulque corpus pinguius obesiusque redditur. Itaque uti morbi, in quibus potus kumis incredibili celeritate opem afferat, omnes opus est, ut in libero aëre, sicuti in tabernaculo, vivas, nullo cibo nisi carnibus vescaris, multumque corpus moveas."

I will not, however, discuss here the physiological properties of koumiss, as I have already described them in my several publications on the subject. What I wish to impress upon my brethren is :

I. 'That the climate itself of Tartary does not give immunity from phthisis, and hence mere residence there would fail to benefit consumptive patients.

2. That the exemption of Tartary, Iceland, and Shetland from phthisis is not a mere coincidence, but arises from one and the same cause, which is common to all three of those countries-viz., the general use of koumiss by the inhabitants.

3. That koumiss alone in Tartary prevents and arrests all those morbid conditions of the body which are the usual precursors of consumption.

4. That the most favoured spot in these British islands for a consumptive patient is his or her own comfortable home, since koumiss can be brought there to work out its marvellous curative power, and thus justify the tribute which Dr. Ucke and others pay to its virtues in styling it " a most excellent, if not the best, remedy for phthisis, both on account of its nourishing properties and healing effects upon the mucous membranes."

\section{REMOVAL OF THE UVULA.}

\section{By E. NOBLE SMI CH, L.R.C.P., M.R.C.S.}

I AM induced to bring this subject before the profession for the following reason. Twenty years ago, the late $\mathrm{Mr}$. Yearsley published these remarks. "Excision of the Uvula. In order to gain all the advantages, and insure no disadvantage, from this operation, it is necessary that the whole of the uvula should be removed, and not part only, as has been the usual practice. It is owing to this partial removal that patients have occasionally been sadly inconvenienced by the irritation kept up, by the food in its passage through the isthm 's striking against the amputated surface. In consequence of such result, Dr. Bennati, a talented physician of Paris, who some years ago used to amp utate the extremity of the uvula in singers, discontinued the practice. In the numerous cases in which I have perform ad total excision, I have never seen such a result. It $m$ ly therefore be set down as an axiom that shortening or snipping the uvula is a most objectionable operation; whereas its entire removal, by which the palatine arches are thrown into one, is an operation which in suitable crses is to bz connended. 